\title{
Identifying and Prioritizing Factors Affecting Sustainable Social Responsibility in a Private Mobile Operator Using Multi-Criteria Decision-Making Techniques
}

\author{
Nastaran Vedad, Tahmoures Sohrabi*
}

\begin{abstract}
Since considering the social factors in organizations in the current era is as important as the income and profitability of organizations, the present study seeks to identify and prioritize the factors affecting sustainable social responsibility. Today's organizations have found that by focusing on social responsibility, they can attract more customers and earn multiple their cost. Since several factors affect the social responsibility of companies, in this paper, first these factors are extracted and then, the factors related to a Private Mobile Operator are identified based on the Delphi method. Since no organization has the ability to define improvement projects for all factors of social responsibility, so they should be ranked to identify the most important factors of limited organizational resources allocated to them. The MABAK method has been used to rank these factors and its required initial weight were extracted by the SAVARA method. Finally, the results of factor prioritization are presented.
\end{abstract}

Keywords: MABAK; MADM; SAVARA; Sustainable Social Responsibility

\section{INTRODUCTION}

Many researchers have recently emphasized Corporate Social Responsibility (CSR) in business contexts and have mentioned CSR as a useful field for many businesses, practitioners, academics and managers [1]. Despite the use of CSR and numerous studies on this concept, there is no agreement on how to conceptualize CSR [2]. However, it is not clear exactly how social responsibility (SR) and sustainable development programs are integrated with corporate practices [3]. According to the existing literature, the integration of sustainability and social responsibility in organizational actions will not only reduce negative environmental impacts and improve social impacts, but will also improve better governance [4], improve financial performance [5] and leads to a better evaluation of the quality of institutions [6]. Accordingly, the present study was conducted with the aim of analysing and prioritizing sustainable social responsibility criteria in a Private Mobile Operator based on the experts' opinion.

\section{PROBLEM STATEMENTS AND RESEARCH LITERATURE}

Corporate social responsibility has been considered by many experts, researchers and organizations so that considering social responsibility has become one of the dimensions and components of their operational activities in organizations [7].

Corporate sustainability, according to Dyllick and Hockerts (2002), is based on six criteria including economic productivity, economic efficiency, environmental effectiveness, social effectiveness, adequacy and economic value [8].

In addition, a matrix is presented in the research of Van Marrewijk and Were (2003) that shows the distinction between organizations at different stages of development, their related institutional frameworks, and the level of performance of different companies. In their view, this matrix is a self-assessment tool that can be used to audit, analyze and interpret corporate sustainability. On the other hand, according to Salzmann, Ionescu-Somers and Steger (2005), firm sustainability is very complex because it is related to different parameters (e.g. technology, organizations and visibility) that vary in different industries, countries and places. However, corporate sustainability, according to them, is limited to reducing operational risk and measures to increase environmental productivity [9].

Accordingly and due to the importance of the research subject, the present study aimed to identify and prioritize sustainable social responsibility indicators in a Private Mobile Operator Therefore, the main question of the present study is what are the most important indicators of sustainable social responsibility in a Private Mobile Operator?

The research literature and background on this subject are reviewed in the following section.

With the advent of the Wall Street movement in the United States and other EU countries, general attitude is that a major part of the causes of these movements and dissatisfaction is caused by the global economic crisis. According to some experts, the lack of attention of organizations to social responsibilities by banks and credit institutions and other institutions and organizations to society caused a major part of this crisis.

A sustainable corporate development model is developed by Sharaei et al. (2017) in a research with the aim of explaining the role of corporate social responsibility, corporate governance, and creating shared value. The research statistical population was 13 companies that won national awards. According to their results, corporate social responsibility and shared value creation affect the development of corporate sustainability with the intensities of $69 \%$ and $63 \%$ and corporate governance improves the relationship between corporate responsibility and creating shared value for stakeholders. Also, it indirectly affects the development of corporate sustainability with an intensity of $27 \%$ [10].

Nadem et al. (2017) examined the effect of social media, transparency and social responsibility on business 
performance with the mediating role of a sustainable brand. Their study aimed to investigate the factors affecting the business performance of Mehr Industrial Group. Data analysis showed that transparency and social responsibility can have a strong relationship with business performance in Mehr Industrial Group and this company must pay close attention to social media and sustainable brand in order to enhance its business performance [11].

The impact of transparency, social responsibility and marketing through social networks on business performance was also investigated by Pirchianloo (2018), considering the mediating role of organizational reputation and sustainable brand. The customers of Digikala Company formed the research statistical population. Content validity (CVR) and convergent (CV) and divergent (DV) constructs were used to evaluate the validity of the questionnaire, and Cronbach's alpha and combined reliability (CR) were used to calculate the reliability of the questionnaire. According to the obtained results, marketing through social networks, reputation building and sustainable brand has a positive and significant effect on business performance.

The integration of social responsibility and sustainability in practice is considered by Filho et al. (2019) by examining attitudes and practices in higher education institutions. According to the existing literature, integrating two related agendas can be problematic according to a range of factors including lack of public awareness or misconceptions about related programs. The attitudes and practices related to the integration of social responsibility and sustainability initiatives in government centres were examined in this research. This study theoretically highlighted the relative position and importance of economic factors - since it relates to differentiate instead of integration, for example social responsibility and sustainability. The main finding of this study was to provide useful insights into how top management can bring together two contemporary but potentially competing agendas [11].

The corporate social responsibility for sustainable social and socio-economic development of small and medium enterprises was also examined by Zuzek and Zvirbule (2018) in Poland and Latvia. The main purpose of this study is to describe the meaning of CSR actions in SME in Poland and In Latvia, considering the possibility of their implementation and the obstacles in their implementation. Their research aimed to: 1) discovering the main areas of CSR related to economic and economic enterprises and sustainable economic and social development; 2) Observation and analysis of key CSR areas for SMEs in Poland and Latvia; 3) Conclusions about the importance of CSR for SMEs in sustainable development [9].

Other research conducted and indicators related to sustainable social responsibility, highlighted by researchers, are provided in Tab. 1.
Table 1 Indicators related to sustainable social responsibility

\begin{tabular}{|c|c|c|}
\hline Dimension & Indicators & Resources \\
\hline \multirow{6}{*}{ Employees } & $\begin{array}{l}\text { Employees' occupational } \\
\text { health and safety }\end{array}$ & \multirow{6}{*}{$\begin{array}{c}{[12],[13],[14],[5]} \\
{[7],[1],[9],[3]}\end{array}$} \\
\hline & $\begin{array}{l}\text { Legal working hours and rest } \\
\text { time }\end{array}$ & \\
\hline & Wages and welfare & \\
\hline & Employment & \\
\hline & Education & \\
\hline & $\begin{array}{l}\text { Freedom of unions and their } \\
\text { bargaining power }\end{array}$ & \\
\hline \multirow{3}{*}{ Shareholders } & Legal shareholder income & \multirow{3}{*}[15]{,$[16]$} \\
\hline & $\begin{array}{l}\text { Accurate disclosure of the } \\
\text { status of companies } \\
\text { and development prospects }\end{array}$ & \\
\hline & $\begin{array}{l}\text { Participation in decision } \\
\text { making }\end{array}$ & \\
\hline \multirow{5}{*}{ Customers } & $\begin{array}{l}\text { Shareholder relationship } \\
\text { management system }\end{array}$ & \multirow{5}{*}[17]{$,[18],[19]$} \\
\hline & $\begin{array}{l}\text { Quality and safety of products } \\
\text { and services }\end{array}$ & \\
\hline & Customer satisfaction & \\
\hline & Customer service culture & \\
\hline & Innovation and development & \\
\hline \multirow{3}{*}{$\begin{array}{l}\text { Suppliers and } \\
\text { Partners }\end{array}$} & $\begin{array}{l}\text { Disclosure of companies' } \\
\text { actual performance } \\
\text { information }\end{array}$ & \multirow{3}{*}[7]{} \\
\hline & Maintaining a partnership & \\
\hline & $\begin{array}{l}\text { Strengthening relationships } \\
\text { with partners / suppliers }\end{array}$ & \\
\hline \multirow{3}{*}{ Government } & $\begin{array}{l}\text { Enhancing CSR performance } \\
\text { of partners and suppliers }\end{array}$ & \multirow{3}{*}[20]{,$[11]$} \\
\hline & Paying tax & \\
\hline & $\begin{array}{l}\text { Following the rules and } \\
\text { regulations }\end{array}$ & \\
\hline \multirow{2}{*}{$\begin{array}{l}\text { Resources and the } \\
\text { environment }\end{array}$} & Providing job opportunities & \multirow[b]{2}{*}{ [21] } \\
\hline & $\begin{array}{l}\text { Preserving energy and } \\
\text { resources }\end{array}$ & \\
\hline \multirow{2}{*}{\begin{tabular}{|l} 
Local \\
communities
\end{tabular}} & Environmental Protection & \multirow{2}{*}[22]{$,[8],[13],[23]$} \\
\hline & Impact of projects on society & \\
\hline \multirow{3}{*}{ Competitors } & $\begin{array}{l}\text { Creating a harmonious } \\
\text { community }\end{array}$ & \multirow{3}{*}{ [9], [17], [24] } \\
\hline & Professional ethics & \\
\hline & Fair competition & \\
\hline NGO & $\begin{array}{l}\text { Social and public service } \\
\text { strategy }\end{array}$ & [25], [26] \\
\hline
\end{tabular}

\section{RESEARCH METHODS}

The present study is an applied research in terms of the purpose because the research results can be applied in the similar organizations. It is also a descriptive survey in terms of data collection approach and the researcher will not interfere in the data. The research statistical population is all experts and experienced managers of a Private Mobile Operator. The dimensions of the present research questionnaire are provided in the table below. In the present study, by examining similar questionnaires, articles, books and journals, initial questionnaires were designed and then, in order to confirm the questionnaire validity, 3 professors were consulted and the questions were reviewed and approved by them. In order to analyze the data obtained from the research questionnaires, first the appropriate weight was assigned to the indicators using the Savara technique and then the indicators were prioritized by the Mabak technique and the experts' opinion was used in each stage [27]. 


\begin{tabular}{|c|c|}
\hline Dimension & Indicators \\
\hline \multirow{6}{*}{ Employees } & Employees' occupational health and safety \\
\hline & Legal working hours and rest time \\
\hline & Wages and welfare \\
\hline & Employment \\
\hline & Education \\
\hline & Freedom of unions and their bargaining power \\
\hline \multirow{4}{*}{ Shareholders } & Legal shareholder income \\
\hline & $\begin{array}{l}\text { Accurate disclosure of the status of companies } \\
\text { and development prospects }\end{array}$ \\
\hline & Participation in decision making \\
\hline & Shareholder relationship management system \\
\hline \multirow{5}{*}{ Customers } & Quality and safety of products and services \\
\hline & Customer satisfaction \\
\hline & Customer service culture \\
\hline & Innovation and development \\
\hline & $\begin{array}{l}\text { Disclosure of companies' actual performance } \\
\text { information }\end{array}$ \\
\hline \multirow{3}{*}{$\begin{array}{l}\text { Suppliers and } \\
\text { Partners }\end{array}$} & Maintaining a partnership \\
\hline & $\begin{array}{l}\text { Strengthening relationships with partners / } \\
\text { suppliers }\end{array}$ \\
\hline & $\begin{array}{l}\text { Enhancing CSR performance of partners and } \\
\text { suppliers }\end{array}$ \\
\hline \multirow{3}{*}{ Government } & Paying tax \\
\hline & Following the rules and regulations \\
\hline & Providing job opportunities \\
\hline \multirow{2}{*}{$\begin{array}{l}\text { Resources and the } \\
\text { environment }\end{array}$} & Preserving energy and resources \\
\hline & Environmental Protection \\
\hline \multirow{2}{*}{ Local communities } & Impact of projects on society \\
\hline & Creating a harmonious community \\
\hline \multirow{2}{*}{ Competitors } & Professional ethics \\
\hline & Fair competition \\
\hline NGO & Social and public service strategy \\
\hline
\end{tabular}

\section{DATA ANALYSIS}

As the sustainable social responsibility variables have been collected from previous research as well as interviews with experts, they should be customized for a Private Mobile Operator. For this purpose, the Delphi method is used and experts were asked to express their opinions on the index by the numbers 1 to 5 by 1 indicating the least important and 5 indicating the most important. If the average of the numbers is less than 4, that variable is rejected and otherwise accepted. There is no agreement among researchers about the number of experts in this method and some believe that this number should be 5 to 15 experts.

Table 3 Experts' preferences about the research indicators

\begin{tabular}{|l|c|c|c|c|c|c|c|c|}
\hline \multicolumn{1}{|c|}{ Factors } & $\begin{array}{c}\text { Expert1 } \\
\text { (E1) }\end{array}$ & E2 & E3 & E4 & E5 & E6 & E7 & M \\
\hline $\begin{array}{l}\text { Employees' } \\
\text { occupational health } \\
\text { and safety }\end{array}$ & 4.29 & 3 & 5 & 4 & 5 & 4 & 5 & 4 \\
\hline $\begin{array}{l}\text { Legal working hours } \\
\text { and rest time }\end{array}$ & 3.57 & 3 & 3 & 4 & 5 & 4 & 3 & 3 \\
\hline Wages and welfare & 4.29 & 3 & 5 & 4 & 5 & 5 & 4 & 4 \\
\hline Employment & 3.57 & 3 & 3 & 4 & 5 & 4 & 3 & 3 \\
\hline Education & 4.29 & 4 & 5 & 3 & 4 & 5 & 4 & 5 \\
\hline $\begin{array}{l}\text { Freedom of unions } \\
\text { and their bargaining } \\
\text { power }\end{array}$ & 4.29 & 4 & 5 & 4 & 3 & 5 & 4 & 5 \\
\hline $\begin{array}{l}\text { Legal shareholder } \\
\text { income }\end{array}$ & 3.57 & 3 & 4 & 5 & 3 & 4 & 3 & 3 \\
\hline
\end{tabular}

\begin{tabular}{|l|l|l|l|l|l|l|l|l|}
\hline $\begin{array}{l}\text { Accurate disclosure } \\
\text { of the status of } \\
\text { companies } \\
\text { and development } \\
\text { prospects }\end{array}$ & 3.71 & 3 & 4 & 5 & 4 & 3 & 4 & 3 \\
\hline $\begin{array}{l}\text { Participation in } \\
\text { decision making }\end{array}$ & 4.29 & 4 & 3 & 4 & 5 & 5 & 4 & 5 \\
\hline $\begin{array}{l}\text { Shareholder } \\
\text { relationship } \\
\text { management system }\end{array}$ & 3.86 & 3 & 3 & 3 & 5 & 4 & 5 & 4 \\
\hline $\begin{array}{l}\text { Quality and safety of } \\
\text { products and services }\end{array}$ & 3.57 & 3 & 4 & 3 & 5 & 4 & 3 & 3 \\
\hline Customer satisfaction & 4.43 & 5 & 3 & 5 & 4 & 5 & 4 & 5 \\
\hline $\begin{array}{l}\text { Customer service } \\
\text { culture }\end{array}$ & 4.43 & 3 & 4 & 5 & 5 & 5 & 4 & 5 \\
\hline $\begin{array}{l}\text { Innovation and } \\
\text { development }\end{array}$ & 3.43 & 4 & 3 & 4 & 3 & 4 & 3 & 3 \\
\hline $\begin{array}{l}\text { Disclosure of } \\
\text { companies' actual } \\
\text { performance } \\
\text { information }\end{array}$ & 3.57 & 3 & 5 & 4 & 3 & 4 & 3 & 3 \\
\hline $\begin{array}{l}\text { Maintaining a } \\
\text { partnership }\end{array}$ & 3.71 & 3 & 5 & 4 & 3 & 4 & 3 & 4 \\
\hline $\begin{array}{l}\text { Strengthening } \\
\text { relationships with } \\
\text { partners / suppliers }\end{array}$ & 3.71 & 5 & 4 & 3 & 3 & 4 & 3 & 4 \\
\hline $\begin{array}{l}\text { Enhancing CSR } \\
\text { performance of } \\
\text { partners and suppliers }\end{array}$ & 4.43 & 3 & 5 & 4 & 5 & 4 & 5 & 5 \\
\hline Paying tax & 4.43 & 3 & 5 & 4 & 5 & 4 & 5 & 5 \\
\hline $\begin{array}{l}\text { Following the rules } \\
\text { and regulations }\end{array}$ & 4.29 & 4 & 5 & 3 & 5 & 4 & 5 & 4 \\
\hline $\begin{array}{l}\text { Providing job } \\
\text { opportunities }\end{array}$ & 4.43 & 4 & 5 & 4 & 4 & 4 & 5 & 5 \\
\hline $\begin{array}{l}\text { Preserving energy and } \\
\text { resources }\end{array}$ & 4.43 & 3 & 5 & 4 & 5 & 4 & 5 & 5 \\
\hline $\begin{array}{l}\text { Environmental } \\
\text { Protection }\end{array}$ & 4.43 & 5 & 3 & 5 & 4 & 5 & 4 & 5 \\
\hline $\begin{array}{l}\text { Impact of projects on } \\
\text { society }\end{array}$ & 4.57 & 4 & 5 & 4 & 5 & 5 & 4 & 5 \\
\hline $\begin{array}{l}\text { Creating a } \\
\text { harmonious } \\
\text { community }\end{array}$ & 5 & 5 & 5 & 4 & 4 & 4 & 3 & 5 \\
\hline Professional ethics & 4.29 & 4 & 5 & 5 & 4 & 5 \\
\hline $\begin{array}{l}\text { Fair competition } \\
\text { Social and public } \\
\text { service strategy }\end{array}$ & 4.57 & 5 & 5 & 4 \\
\hline
\end{tabular}

The results of the experts' opinion in the Delphi method are presented in the following table.

Table 4 Delphi method calculation results

\begin{tabular}{|l|c|}
\hline \multicolumn{1}{|c|}{ Variables } & Reject / Accept \\
\hline Employees' occupational health and safety & Accept \\
\hline Legal working hours and rest time & Reject \\
\hline Wages and welfare & Accept \\
\hline Employment & Reject \\
\hline Education & Accept \\
\hline Freedom of unions and their bargaining power & Accept \\
\hline Legal shareholder income & Reject \\
\hline $\begin{array}{l}\text { Accurate disclosure of the status of companies } \\
\text { and development prospects }\end{array}$ & Reject \\
\hline Participation in decision making & Accept \\
\hline Shareholder relationship management system & Reject \\
\hline Quality and safety of products and services & Reject \\
\hline Customer satisfaction & Accept \\
\hline Customer service culture & Accept \\
\hline Innovation and development & Reject \\
\hline $\begin{array}{l}\text { Disclosure of companies' actual performance } \\
\text { information }\end{array}$ & Reject \\
\hline
\end{tabular}




\begin{tabular}{|l|c|}
\hline Maintaining a partnership & Reject \\
\hline Strengthening relationships with partners / suppliers & Reject \\
\hline Enhancing CSR performance of partners and suppliers & Accept \\
\hline Paying tax & Accept \\
\hline Following the rules and regulations & Accept \\
\hline Providing job opportunities & Accept \\
\hline Preserving energy and resources & Accept \\
\hline Environmental Protection & Accept \\
\hline Impact of projects on society & Accept \\
\hline Creating a harmonious community & Accept \\
\hline Professional ethics & Accept \\
\hline Fair competition & Accept \\
\hline Social and public service strategy & Accept \\
\hline
\end{tabular}

According to the obtained results, among 28 variables, 10 variables were rejected and 18 variables were accepted based on the experts' opinion. Because each of the respondents have different opinions according to their expertise and background. Therefore, the weight of each opinion is different, so the Savara method is used to obtain these weights.

Table 5 Initial weights obtained by Savara method
\begin{tabular}{|c|c|c|c|c|}
\hline Factor & $\begin{array}{c}\text { Comparative } \\
\text { importance of } \\
\text { average value } \\
\left(S_{j}\right)\end{array}$ & $\begin{array}{c}\text { Coefficient } \\
K_{j}=S_{j}+1\end{array}$ & $\begin{array}{c}\text { Recalculated } \\
\text { weight } \\
W_{j}=\frac{x_{j-1}}{K_{j}}\end{array}$ & $\begin{array}{c}\text { Weight } \\
q_{j}=\frac{W_{j}}{\sum W_{j}}\end{array}$ \\
\hline Expert 1 & 0.33 & 1 & 1 & - \\
\hline Expert 2 & 0.17 & 0.52 & 1.94 & 0.94 \\
\hline Expert 3 & 0.09 & 0.27 & 1.81 & 0.81 \\
\hline Expert 4 & 0.09 & 0.28 & 1.71 & 0.71 \\
\hline Expert 5 & 0.1 & 0.3 & 1.63 & 0.63 \\
\hline Expert 6 & 0.1 & 0.32 & 1.49 & 0.49 \\
\hline Expert 7 & 0.11 & 0.35 & 1.37 & 0.37 \\
\hline
\end{tabular}

Step 1: creating the initial matrix (average of respondents). The input weights of the Mabak technique can be obtained from other methods such as AHP, entropy, etc. that these weights is obtained by Savara method in this study and will be used in Mabak process. All indicators are considered positive [28].

Table 6 Initial decision matrix

\begin{tabular}{|l|c|c|c|c|c|c|c|}
\hline \multicolumn{1}{|c}{ Index name } & E1 & E2 & E3 & E4 & E5 & E6 & E7 \\
\hline $\begin{array}{l}\text { Participate in decision } \\
\text { making }\end{array}$ & 4 & 5 & 7 & 6 & 9 & 7 & 8 \\
\hline $\begin{array}{l}\text { Customer service } \\
\text { culture }\end{array}$ & 8 & 7 & 6 & 7 & 9 & 8 & 9 \\
\hline Customer satisfaction & 7 & 5 & 8 & 6 & 7 & 6 & 9 \\
\hline $\begin{array}{l}\text { Impact of projects on } \\
\text { society }\end{array}$ & 7 & 6 & 5 & 3 & 4 & 6 & 6 \\
\hline Professional ethics & 7 & 6 & 9 & 8 & 6 & 8 & 7 \\
\hline $\begin{array}{l}\text { Employees' } \\
\text { occupational health and } \\
\text { safety }\end{array}$ & 9 & 7 & 6 & 9 & 8 & 9 & 9 \\
\hline $\begin{array}{l}\text { Following the rules and } \\
\text { regulations }\end{array}$ & 7 & 7 & 7 & 4 & 4 & 5 & 5 \\
\hline $\begin{array}{l}\text { Preserving energy and } \\
\text { resources }\end{array}$ & 5 & 5 & 8 & 7 & 6 & 9 & 6 \\
\hline $\begin{array}{l}\text { Providing job } \\
\text { opportunities }\end{array}$ & 5 & 8 & 4 & 5 & 4 & 6 & 6 \\
\hline $\begin{array}{l}\text { Improving CSR } \\
\text { performance of partners } \\
\text { and suppliers }\end{array}$ & 5 & 5 & 7 & 9 & 5 & 9 & 5 \\
\hline Education & 4 & 9 & 9 & 8 & 6 & 7 & 5 \\
\hline
\end{tabular}

\begin{tabular}{|l|c|c|c|c|c|c|c|}
\hline $\begin{array}{l}\text { Social and public } \\
\text { service strategy }\end{array}$ & 9 & 9 & 5 & 4 & 4 & 9 & 9 \\
\hline Fair competition & 7 & 6 & 6 & 6 & 8 & 5 & 4 \\
\hline $\begin{array}{l}\text { Creating a harmonious } \\
\text { community }\end{array}$ & 4 & 7 & 6 & 6 & 9 & 4 & 5 \\
\hline $\begin{array}{l}\text { Environmental } \\
\text { Protection }\end{array}$ & 4 & 4 & 7 & 8 & 4 & 6 & 9 \\
\hline Wages and welfare & 8 & 4 & 6 & 9 & 4 & 6 & 7 \\
\hline Paying tax & 4 & 5 & 4 & 5 & 4 & 9 & 5 \\
\hline $\begin{array}{l}\text { Freedom of association } \\
\text { and their bargaining } \\
\text { power }\end{array}$ & 5 & 5 & 9 & 5 & 6 & 6 & 8 \\
\hline Maximum & 8 & 9 & 9 & 9 & 9 & 9 & 9 \\
\hline Minimum & 4 & 4 & 4 & 3 & 4 & 4 & 4 \\
\hline Weight & 0.11 & 0.1 & 0.1 & 0.09 & 0.09 & 0.17 & 0.33 \\
\hline
\end{tabular}

Step 2: normalization [29]: the data is normalized in this step, which is presented in the table below.

\begin{tabular}{|c|c|c|c|c|c|c|c|}
\hline Index name & E1 & $\mathrm{E} 2$ & E3 & E4 & E5 & E6 & E7 \\
\hline $\begin{array}{l}\text { Participate in decision } \\
\text { making }\end{array}$ & 0 & 0.2 & 0.6 & 0.5 & 1 & 0.6 & 0.8 \\
\hline $\begin{array}{l}\text { Customer service } \\
\text { culture }\end{array}$ & 1 & 0.6 & 0.4 & 0.67 & 1 & 0.8 & 1 \\
\hline Customer satisfaction & 0.75 & 0.2 & 0.8 & 0.5 & 0.6 & 0.4 & 1 \\
\hline $\begin{array}{l}\text { Impact of projects on } \\
\text { society }\end{array}$ & 0.75 & 0.4 & 0.2 & 0 & 0 & 0.4 & 0.4 \\
\hline Professional ethics & 0.75 & 0.4 & 1 & 0.83 & 0.4 & 0.8 & $\overline{0.6}$ \\
\hline $\begin{array}{l}\text { Employees' } \\
\text { occupational health } \\
\text { and safety }\end{array}$ & 0 & 1 & 0.8 & 1 & 0.4 & 0.2 & 0.2 \\
\hline $\begin{array}{l}\text { Following the rules } \\
\text { and regulations }\end{array}$ & 1 & 0 & 0 & 0.33 & 0.2 & 0.4 & 0 \\
\hline $\begin{array}{l}\text { Preserving energy and } \\
\text { resources }\end{array}$ & 1 & 0.6 & 0.8 & 0.33 & 0.4 & 0 & 0.4 \\
\hline $\begin{array}{l}\text { Providing job } \\
\text { opportunities }\end{array}$ & 0.75 & 0 & 0.4 & 0.5 & 0.2 & 0 & 0.4 \\
\hline $\begin{array}{l}\text { Improving CSR } \\
\text { performance of } \\
\text { partners and suppliers }\end{array}$ & 0.25 & 0.8 & 0.2 & 0.5 & 1 & 0.2 & 0.6 \\
\hline Education & 0.75 & 0 & 0.2 & 0.67 & 0 & 0.8 & 0 \\
\hline $\begin{array}{l}\text { Social and public } \\
\text { service strategy }\end{array}$ & 0.25 & 0 & 0.6 & 1 & 0.8 & 1 & 0 \\
\hline Fair competition & 0.5 & 0.4 & 0.4 & 0.33 & 0.6 & 1 & 0.8 \\
\hline $\begin{array}{l}\text { Creating a harmonious } \\
\text { community }\end{array}$ & 0 & 0.2 & 0.6 & 0.5 & 1 & 0.6 & 0.8 \\
\hline $\begin{array}{l}\text { Environmental } \\
\text { Protection }\end{array}$ & 1 & 0.6 & 0.4 & 0.67 & 1 & 0.8 & 1 \\
\hline Wages and welfare & 0.75 & 0.2 & 0.8 & 0.5 & 0.6 & 0.4 & 1 \\
\hline Paying tax & 0.75 & 0.4 & 0.2 & 0 & 0 & 0.4 & 0.4 \\
\hline $\begin{array}{l}\text { Freedom of } \\
\text { association and their } \\
\text { bargaining power }\end{array}$ & 0.75 & 0.4 & 1 & 0.83 & 0.4 & 0.8 & 0.6 \\
\hline
\end{tabular}

Step 3: creating a weighted matrix: a weighted matrix is formed in this step and the results are presented in the Tab. 8.

Table 8 The weighted matrix

\begin{tabular}{|l|c|c|c|c|c|c|c|}
\hline \multicolumn{1}{|c|}{ Index name } & E1 & E2 & E3 & E4 & E5 & E6 & E7 \\
\hline $\begin{array}{l}\text { Participate in } \\
\text { decision making }\end{array}$ & 0.11 & 0.13 & 0.16 & 0.14 & 0.18 & 0.27 & 0.59 \\
\hline $\begin{array}{l}\text { Customer service } \\
\text { culture }\end{array}$ & 0.23 & 0.17 & 0.14 & 0.16 & 0.18 & 0.31 & 0.66 \\
\hline $\begin{array}{l}\text { Customer } \\
\text { satisfaction }\end{array}$ & 0.2 & 0.13 & 0.18 & 0.14 & 0.14 & 0.24 & 0.66 \\
\hline $\begin{array}{l}\text { Impact of projects } \\
\text { on society }\end{array}$ & 0.2 & 0.15 & 0.12 & 0.09 & 0.09 & 0.24 & 0.46 \\
\hline
\end{tabular}


Nastran Vedad, Tahmoures Sohrabi: Identifying and Prioritizing Factors Affecting Sustainable Social Responsibility in a Private Mobile Operator

\begin{tabular}{|l|c|c|c|c|c|c|c|}
\hline Professional ethics & 0.2 & 0.15 & 0.2 & 0.17 & 0.12 & 0.31 & 0.53 \\
\hline $\begin{array}{l}\text { Employees' } \\
\text { occupational } \\
\text { health and safety }\end{array}$ & 0.11 & 0.21 & 0.18 & 0.19 & 0.12 & 0.2 & 0.4 \\
\hline $\begin{array}{l}\text { Following the } \\
\text { rules and } \\
\text { regulations }\end{array}$ & 0.23 & 0.1 & 0.1 & 0.13 & 0.11 & 0.24 & 0.33 \\
\hline $\begin{array}{l}\text { Preserving energy } \\
\text { and resources }\end{array}$ & 0.23 & 0.17 & 0.18 & 0.13 & 0.12 & 0.17 & 0.46 \\
\hline $\begin{array}{l}\text { Providing job } \\
\text { opportunities }\end{array}$ & 0.2 & 0.1 & 0.14 & 0.14 & 0.11 & 0.17 & 0.46 \\
\hline $\begin{array}{l}\text { Improving CSR } \\
\text { performance of } \\
\text { partners and } \\
\text { suppliers }\end{array}$ & 0.14 & 0.19 & 0.12 & 0.14 & 0.18 & 0.2 & 0.53 \\
\hline Education & 0.2 & 0.1 & 0.12 & 0.16 & 0.09 & 0.31 & 0.33 \\
\hline $\begin{array}{l}\text { Social and public } \\
\text { service strategy }\end{array}$ & 0.14 & 0.1 & 0.16 & 0.19 & 0.16 & 0.34 & 0.33 \\
\hline Fair competition & 0.17 & 0.15 & 0.14 & 0.13 & 0.14 & 0.34 & 0.59 \\
\hline $\begin{array}{l}\text { Participate in } \\
\text { decision making }\end{array}$ & 0.2 & 0.15 & 0.18 & 0.17 & 0.12 & 0.34 & 0.4 \\
\hline $\begin{array}{l}\text { Customer service } \\
\text { culture }\end{array}$ & 0.11 & 0.17 & 0.16 & 0.13 & 0.11 & 0.24 & 0.4 \\
\hline $\begin{array}{l}\text { Customer } \\
\text { satisfaction }\end{array}$ & 0.2 & 0.17 & 0.2 & 0.16 & 0.12 & 0.2 & 0.33 \\
\hline $\begin{array}{l}\text { Impact of projects } \\
\text { on society }\end{array}$ & 0.23 & 0.13 & 0.12 & 0.16 & 0.09 & 0.2 & 0.46 \\
\hline Professional ethics & 0.11 & 0.17 & 0.2 & 0.16 & 0.12 & 0.31 & 0.33 \\
\hline
\end{tabular}

\begin{tabular}{|l|c|c|c|c|c|c|c|}
\hline $\begin{array}{l}\text { Participate in } \\
\text { decision } \\
\text { making }\end{array}$ & -0.98 & -1 & -0.98 & -0.98 & -1 & -0.9 & -0.96 \\
\hline $\begin{array}{l}\text { Customer } \\
\text { service culture }\end{array}$ & -1.07 & -0.98 & -1 & -1.02 & -1.02 & -1.01 & -0.96 \\
\hline $\begin{array}{l}\text { Customer } \\
\text { satisfaction }\end{array}$ & -0.98 & -0.98 & -0.96 & -0.99 & -1 & -1.04 & -1.02 \\
\hline $\begin{array}{l}\text { Impact of } \\
\text { projects on } \\
\text { society }\end{array}$ & -0.95 & -1.02 & -1.04 & -0.99 & -1.04 & -1.04 & -0.98 \\
\hline $\begin{array}{l}\text { Professional } \\
\text { ethics }\end{array}$ & -1.07 & -0.98 & -0.96 & -0.99 & -1 & -0.94 & -1.02 \\
\hline
\end{tabular}

Step 5: ranking alternatives. The results are shown in the table below.

Table 10 Ranking Options
\begin{tabular}{|l|c|c|}
\hline \multicolumn{1}{|c|}{ Index } & Weight & Rank \\
\hline Participate in decision making & 5 & -6.78 \\
\hline Customer service culture & 1 & -6.53 \\
\hline Customer satisfaction & 2 & -6.67 \\
\hline Impact of projects on society & 14 & -7.01 \\
\hline Professional ethics & 3 & -6.68 \\
\hline Employees' occupational health and safety & 10 & -6.95 \\
\hline Following the rules and regulations & 18 & -7.13 \\
\hline Preserving energy and resources & 8 & -6.9 \\
\hline Providing job opportunities & 15 & -7.04 \\
\hline Improving CSR performance of partners and suppliers & 7 & -6.86 \\
\hline Education & 17 & -7.05 \\
\hline Social and public service strategy & 9 & -6.94 \\
\hline Fair competition & 4 & -6.7 \\
\hline Participate in decision making & 6 & -6.8 \\
\hline Customer service culture & 16 & -7.05 \\
\hline Customer satisfaction & 13 & -6.98 \\
\hline Impact of projects on society & 12 & -6.97 \\
\hline Professional ethics & 11 & -6.96 \\
\hline
\end{tabular}

\section{CONCLUSIONS}

Corporate social responsibility, as an initiative of public relations professionals, was ignored in the United States in the early 1990s because critics argued that it was an attempt to rebuild the damaged reputation of some and make a company different from its competitors. Today, however, many businesses adopted social responsibility as a smart business measure.

Corporate Social Responsibility (CSR) has become a sensitive and important issue in recent years. As accountable organizations, leading organizations express their values to make their performance transparent to their stakeholders and to fulfill their responsibilities in the area of social responsibility, and to ensure that these commitments are deployed throughout the organization. Therefore, social responsibility will have mutual benefits for them, so that the organization benefits from a more ethical and coherent approach and the community and stakeholders have a better understanding of the organization performance and strengths $[30,31,32]$.

The aim of this study was to identify and prioritize the factors affecting sustainable social responsibility in a Private Mobile Operator using the multi-criteria decision-making technique and prioritize these factors. For this purpose, first 28 factors were extracted based on previous research and interviews with experts. Then, it is tried to align these factors 
with a Private Mobile Operator by the Delphi method. The results of Delphi method showed that out of these 28 factors, 18 factors were accepted and 10 factors were rejected. Now, these factors should be ranked to help a Private Mobile Operator by identifying the most important factors so that it can play its social responsibility role in the best way and allocate its limited resources to the most important factors. The Mabak method was used to prioritize these factors, and since prioritization by this method requires initial weight, the Savara method was used to obtain the initial weight. According to the obtained results, among the 18 factors of sustainable social responsibility in a Private Mobile Operator 1 , the culture of customer service has the highest degree of importance. This means that if a Private Mobile Operator wants to achieve a high degree of sustainable social responsibility, it must strive to spread the culture of customer service throughout the company. a Private Mobile Operator Company has now serious and important competitors in the field of providing services, some of which, including Hamrahe Aval, are supported by the government. This government support can help Hamrahe Aval to provide better services and ultimately more profit. By focusing on this index, a Private Mobile Operator Company can fulfill its sustainable social responsibility and can gain a competitive advantage, surpassing its first or other competitors [33].

Difficult access to research experts due to their job as managers of the company under study was one of the limitations of the present study. Also, in this study, it was necessary to use two questionnaires to implement a combined method of Savara and Mabak, and therefore, due to the large number of criteria and sub-criteria, the number of tables in the TOPSIS method to be completed by experts was high and this led to a decreased reliability of the experts' answers and the length of the research process. As a suggestion for the future research, this model can be implemented in other companies in the telecommunications industry or can also be solved with other MADM methods such as WASPAS, MULTIMOORA, and so on.

\section{REFERENCES}

[1] Barber, M. (2004), Public Administration and sustainable Development. Plymouth, MacDonald \& Evans Ltd.

[2] Benn, S., Dunphy, D., \& Griffiths, A. (2014). Organizational change for corporate sustainability. Routledge, London, UK and New York, USA. https://doi.org/10.4324/9781315819181

[3] Branco, M. C., \& Rodrigues, L. L. (2006). Corporate social responsibility and resource-based perspectives. Journal of Business Ethics, 69(2), 111-132. https://doi.org/10.1007/s10551-006-9071-z

[4] Camilleri, M. A (2017). Corporate sustainability and responsibility: creating value for business, society and the environment. Asian Journal of Sustainability and Social Responsibility, 2, 59-74.

https://doi.org/10.1186/s41180-017-0016-5

[5] Caroll, A. B. (1991). The pyramid of corporate social responsibility: Toward the moral management of organizational stakeholders. Business Horizons, 34(4), 39-48. https://doi.org/10.1016/0007-6813(91)90005-G

[6] Carroll, A. B. \& Buchholts, B. (2003). The Business/Society Relationship. Ethics and Stakeholder Management, 5.
[7] Dyllick, T. \& Hockerts, K. (2002). Beyond the business case for corporate sustainability. Business strategy and the environment, 11, 130-141. https://doi.org/10.1002/bse.323

[8] Ebner, D. \& Baumgartner, R. J. (2008). The relationship between Sustainable Development and Corporate Social Responsibility. CRRC 2008: Corporate Responsibility Research Conference, 4-5, September, Dublin.

[9] Famiyeh, S. (2017). Corporate social responsibility and firm's performance: Empirical evidence. Soc. Responsib. J., 13, 390406. https://doi.org/10.1108/SRJ-04-2016-0049

[10] Filho, W. L., Doni, F., Vargas, V. R., Wall, T., Hindley, A., Rayman-Bacchus, L., \& Avila, L. V. (2019). The integration of social responsibility and sustainability in practice: exploring attitudes and practices in Higher Education Institutions. Journal of Cleaner Production, 220, 152-166. https://doi.org/10.1016/j.jclepro.2019.02.139

[11] Ganescu, M. C. (2012). Corporate social responsibility, a strategy to create and consolidate sustainable businesses, Theoretical and Applied Economics, 11(576), 91-106.

[12] Barney, J. B. \& Griffin, R. W. (1992). The Management of Organization: Strategy, Structure, Behavior. Houghton Mifflin Company, 820 pages.

[13] Holme, R. \& Watts. P. (2000). Corporate social responsibility: making good business sense. Word Business Council for Sustainable Development.

[14] Kansal, M., Joshi, M., \& Singh Batra, G. (2014). Determinants of corporate social responsibility disclosures: Evidence from India. Advances in Accounting, 30(1). https://doi.org/10.1016/j.adiac.2014.03.009

[15] Mele, D. \& Guillen, M. (2006). The Intellectual Evolution of Strategic Management and Its Relationship with Ethics and Social Responsibility. Working Paper. No. 658. IESE Business School, University of Navarra, P. 3. https://doi.org/10.2139/ssrn.960663

[16] Montiel, I. (2008). Corporate social responsibility and corporate sustainability separate pasts, common futures. Organization \& Environment, 21, 245-269. https://doi.org/10.1177/1086026608321329

[17] Moir, L. (2001). What do we mean by corporate social responsibility? Corp. Gov. Int. J. Bus. Soc., 1, 16-22. https://doi.org/10.1108/EUM0000000005486

[18] Ntim, C. G. \& Soobaroyen, T. (2013). Corporate governance and performance in socially responsible corporations: new empirical insights from a neo-institutional framework. Corp. Govern. Int. Rev., 21(5), 468-494. https://doi.org/10.1111/corg.12026

[19] Persons, O. (2012). Incorporating corporate social responsibility and sustainability into a business course: a shared experience. J. Educ. Bus., 87(2), 63-72. https://doi.org/10.1080/08832323.2011.562933

[20] Peloza, J. \& Green, T. (2011). How does corporate social responsibility create value for consumers? J. Consum. Mark., 28, 48-56. https://doi.org/10.1108/07363761111101949

[21] Rezaei, J. (2016). Best-worst multi-criteria decision-making method: Some properties and a linear model. Omega, 64, 126130. https://doi.org/10.1016/j.omega.2015.12.001

[22] Saeidi, S. P., Sofian, S., Saeidi, P., Saeidi, S. P., \& Saaeidi, S. A. (2015). How does corporate social responsibility contribute to firm financial performance? The mediating role of competitive advantage, reputation, and customer satisfaction? J. Bus. Res., 68(2), 341-350. https://doi.org/10.1016/j.jbusres.2014.06.024

[23] Salzmann, O., Ionescu-Somers, A., \& Steger, U. (2005). The business case for corporate sustainability: Literature review 
and research options. European Management Journal, 23, $27-$ 36. https://doi.org/10.1016/j.emj.2004.12.007

[24] Schüz, M. (2012). Sustainable Corporate Responsibility - The Foundation of Successful Business in the New Millennium. European Business Review, 1(2), 7-18. https://doi.org/10.18267/j.cebr.12

[25] Silveira, L. M. \& Petrini, M. (2018). Sustainable Development and Corporate Social Responsibility: a bibliometric analysis of International Scientific Production, Gest. Prod., 25(1), 56-67. https://doi.org/10.1590/0104-530x3173-16

[26] Tsoutsoura, M. (2004). Corporate Social Responsibility and Financial 99-Performance. Working Paper. Haas School of Business. University of California.

[27] Valor, C. (2005). Corporate social responsibility and corporate citizenship: Towards corporate accountability. Business and society review, 110, 191-212. https://doi.org/10.1111/j.0045-3609.2005.00011.x

[28] Van Marrewijk, M. (2003). Concepts and definitions of CSR and corporate sustainability: Between agency and communion. Journal of business ethics, 44, 95-105. https://doi.org/10.1023/A:1023331212247

[29] Van Marrewijk, M. \& Werre, M. (2003). Multiple levels of corporate sustainability. Journal of Business Ethics, 107-119. https://doi.org/10.1023/A:1023383229086

[30] Visser, W. (2010). The age of responsibility: CSR 2.0 and the New DNA of business. Journal of business systems, governance and ethics, 5(3), 7. https://doi.org/10.15209/jbsge.v5i3.185

[31] Visser, W. (2011). The age of responsibility: CSR 2.0 and the new DNA of business. John Wiley and Sons, Chichester, UK. https://doi.org/10.15209/jbsge.v5i3.185

[32] Weerts, D. J. \& Sandmann, L. R. (2010). Community engagement and boundary spanning roles at research universities. J. High. Educ., 81(6), 632-657. https://doi.org/10.1080/00221546.2010.11779075

[33] Zhao, Z.-Y., Zhao, X.-J., Davidson, K., \& Zuo, J. (2012). A corporate social responsibility indicator system for construction enterprises. Journal of Cleaner Production, 2930, 277-289. https://doi.org/10.1016/j.jclepro.2011.12.036

\section{Authors' contacts:}

Nastaran Vedad, M.Sc. Student of Management Business Administration in Technology,

Faculty of Management,

Islamic Azad University,

Central Tehran Branch,

Tehran, Iran

nastran.vadad.2020@gmail.com

Tahmoures Sohrabi, Dr., Assistant Professor

(Corresponding author)

Faculty of Management,

Islamic Azad University,

Central Tehran Branch,

Tehran, Iran

dr.tahmoures.sohrabi@gmail.com 